\title{
Sites in the Polyoma Genome Cleaved by Restriction Endonuclease HindII
}

\author{
WILLIAM R. FOLK, BARBARA R. FISHEL, AND DAVID M. ANDERSON \\ Department of Biological Chemistry, The University of Michigan, Ann Arbor, Michigan 48104
}

Accepted October 28, 1974

\begin{abstract}
The Hemophilus influenzae HindII endonuclease cleaves polyoma DNA into two fragments, approximately 90 and $10 \%$ the size of polyoma linear DNA. One of the HindII sites is located in the $H$. parainfluenzae HpaII-F fragment, and the other in the HpaII-A fragment. Both sites have the sequence CAGCTG
\end{abstract}

Restriction endonucleases are powerful tools with which to study the structure and function of DNA. In particular, endonuclease fragments from SV $-40, \lambda$ and $\phi \times 174$ DNA's have provided new insights into viral gene expression and replication $(1-7)$. Recently, the sites of cleavage of a number of restriction endonucleases in polyoma DNA were ordered (8). In this report we add to that list the locations of the two sites cleaved by the HindII restriction endonuclease.

Pasadena large plaque polyoma ${ }^{32} \mathrm{P}$ labeled DNA was purified from infected secondary whole mouse embryo cells or mouse 3T6 cells as previously described (9). Care was taken to use low passage virus to minimize the level of defectives ( 9 , 10). Restriction endonucleases were purified from Hemophilus influenzae $\mathrm{Rd}$ and $H$. parainfluenzae by procedures slightly modified from those described by Smith and Wilcox (11) or Sharp, Sugden and Sambrook (12). Digestions were performed at $37^{\circ}$ in buffers containing $10 \mathrm{mM}$ Tris $-\mathrm{Cl}$ (pH 7.4), $6.6 \mathrm{mM} \mathrm{MgCl}, 6 \mathrm{mM}$ mercaptoethanol and $60 \mathrm{mM} \mathrm{NaCl}$ (for HindII and HindIII) or $10 \mathrm{~m} M$ Tris-Cl (pH 7.4), 10 $\mathrm{m} M \mathrm{MgCl}_{2}, 1 \mathrm{~m} M$ dithiothreitol and $6 \mathrm{~m} M$ $\mathrm{KCl}$ (for $\mathrm{HpaI}$ and $\mathrm{HpaII}$ ). HindII was separated from HindIII by chromatogra- phy on DEAE-cellulose (13; D. Nathans, personal communication). Slab gel electrophoresis was performed as described by Danna and Nathans (13) using $4 \%$ acrylamide gels at $20^{\circ}$ in buffer without sodium dodecyl sulfate (SDS). For analytical purposes, gels were dried under vacuum and autoradiographed. For preparative purposes, the gels were autoradiographed, and DNA fragments were eluted from the minced gels with $10 \mathrm{~m} M$ Tris- $\mathrm{Cl}, 1 \mathrm{~m} M$ EDTA, pH 7.5.

$H$. influenzae $\mathrm{Rd}$ contains at least two restriction endonucleases, HindII and HindIII (13-15). HindIII recognizes the se-

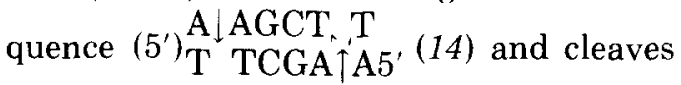
polyoma DNA into two fragments, approximately 44 and $56 \%$ the size of the genome (8; Table 1, Fig. 1). The other restriction endonuclease. HindII, recognizes the sequence $\quad\left(5^{\prime}\right)$ GTPy $\downarrow$ CAPu $\uparrow$ PuTC $5^{\prime} \quad(14-16) \quad$ and cleaves polyoma into two fragments, whose sizes are approximately 9 and $90 \%$ the size of the polyoma genome (Table 1, Fig. 1). A mixture of HindII and HindIII cuts polyoma DNA into four fragments, of which the largest has the same size as the larger fragment produced by HindIII (Table 1, Fig. 1). Thus the two sites recognized by 
TABLE 1

Size or Polyoma DNA Fragiments Obtained by Digestion with $H$. influenzae Endonucleases

\begin{tabular}{|c|c|c|}
\hline $\begin{array}{c}\text { DNA } \\
\text { substrate }\end{array}$ & Fndonuclease & $\begin{array}{l}\text { Fragments } \\
\text { produced }(\%)^{a}\end{array}$ \\
\hline Polyoma & HindIII & $\begin{array}{l}56^{b}(\text { HindIII A) } \\
44(\text { HindIII B) }\end{array}$ \\
\hline Polyoma & HindII & $\begin{array}{c}90^{r}(\text { HindII A }) \\
9.5(\text { HindII B })\end{array}$ \\
\hline Polyoma & HindII + HindIII & $\begin{array}{l}56^{b}(\text { HindIII A) } \\
26 \\
9.5(\text { HindII B) } \\
8.2\end{array}$ \\
\hline HpaII-A & 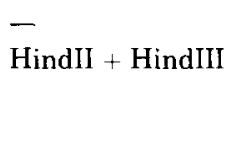 & $\begin{array}{c}27.3^{b} \\
9.5 \\
9.0 \\
8.2\end{array}$ \\
\hline Hpall-B & $\overline{-}$ HindII + HindIII & $\begin{array}{l}21.4^{\circ} \\
18 \\
2.8\end{array}$ \\
\hline HpaII-F & 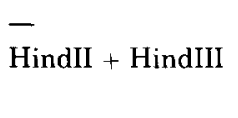 & $\begin{array}{r}6.7^{b} \\
6.5 \\
<1.5\end{array}$ \\
\hline $\begin{array}{l}\text { Hpall-C,D,E, } \\
\text { G,H }\end{array}$ & HindII + HindIII & 0 \\
\hline
\end{tabular}

${ }^{a}$ Unless otherwise noted, values given are in percent of polyoma genome, determined from mobilities in $4 \%$ polyacrylamide gels with HpaII fragments as standards.

${ }^{b}$ From Griffin et al. (8).

" From comparison of sedimentation rate through neutral sucrose gradient with polyoma linear DNA as reference $(9)$.

the HindII endonuclease are contained within the smaller fragment produced by the HindIII endonuclease.

To determine the locations of the sites cleaved by the HindII endonuclease, polyoma DNA was cleaved with the HpaII restriction endonuclease, and the eight fragments produced by this enzyme (8) were purified. Each fragment was incu- bated with a mixture of the HindII and HindIII enzymes, and the products separated by acrylamide slab gel electrophoresis. Fragments C, D, E, G and $\mathrm{H}^{1}$ had identical mobilities before and after digestion (Fig. 1) indicating they did not contain sites for either enzyme. HpaII-B was cleaved once, into two pieces approximately 18 and $2.8 \%$ the size of the polyoma genome (Table 1, Fig. 1). This cleavage occurs at one of the previously mapped HindIII sites (8). HpalI-A was cleaved into three pieces, two of approximately $9.5 \%$ and one of $8.2 \%$ of the polyoma genome (Table 1, Fig. 1). The smaller fragment is produced by the HindIII activity at the previously mapped second HindIII site in the polyoma genome. The other pieces from HpaII-A are generated by the HindII activity at a site approximately in the middle of the larger fragment produced by HindIII. The HpaII-F fragment is cleaved into two pieces, one of approximately $6.4 \%$ of the genome and the other of less than $1.5 \%$ of the genome (Table 1, Fig. 1). (This is a maximum estimate of the size of the small fragment, as it runs ahead or with the marker dye and is not visible on the radioautograph.) Thus, the HpaII-F fragment contains the second HindII site. A map of the circular polyoma genome illustrating the various restriction endonuclease sites is given in Fig. 2.

Assignment of nucleotide sequences to the sites cleaved by the Hpa and Hind restriction endonucleases can be made, now that the specificities of both sets of enzymes are established (14-17). In agreement with Griffin et al. (8), we find that the Hpal endonuclease, which recognizes the sequence (5') GTT CAAAC (16), does not cleave polyoma DNA. As this sequence is one of the two recognized by HindII (17), the sites in HpaII-A and HpaII-F cleaved by HindII must have the sequence

\footnotetext{
${ }^{1}$ In accordance with the suggested nomenclature for fragments of DNA generated by restriction endonucleases (14), the fragments Hpall 1-8 described by Griffin et $a l$. (8) are referred to as HpaII-A-H.
} 


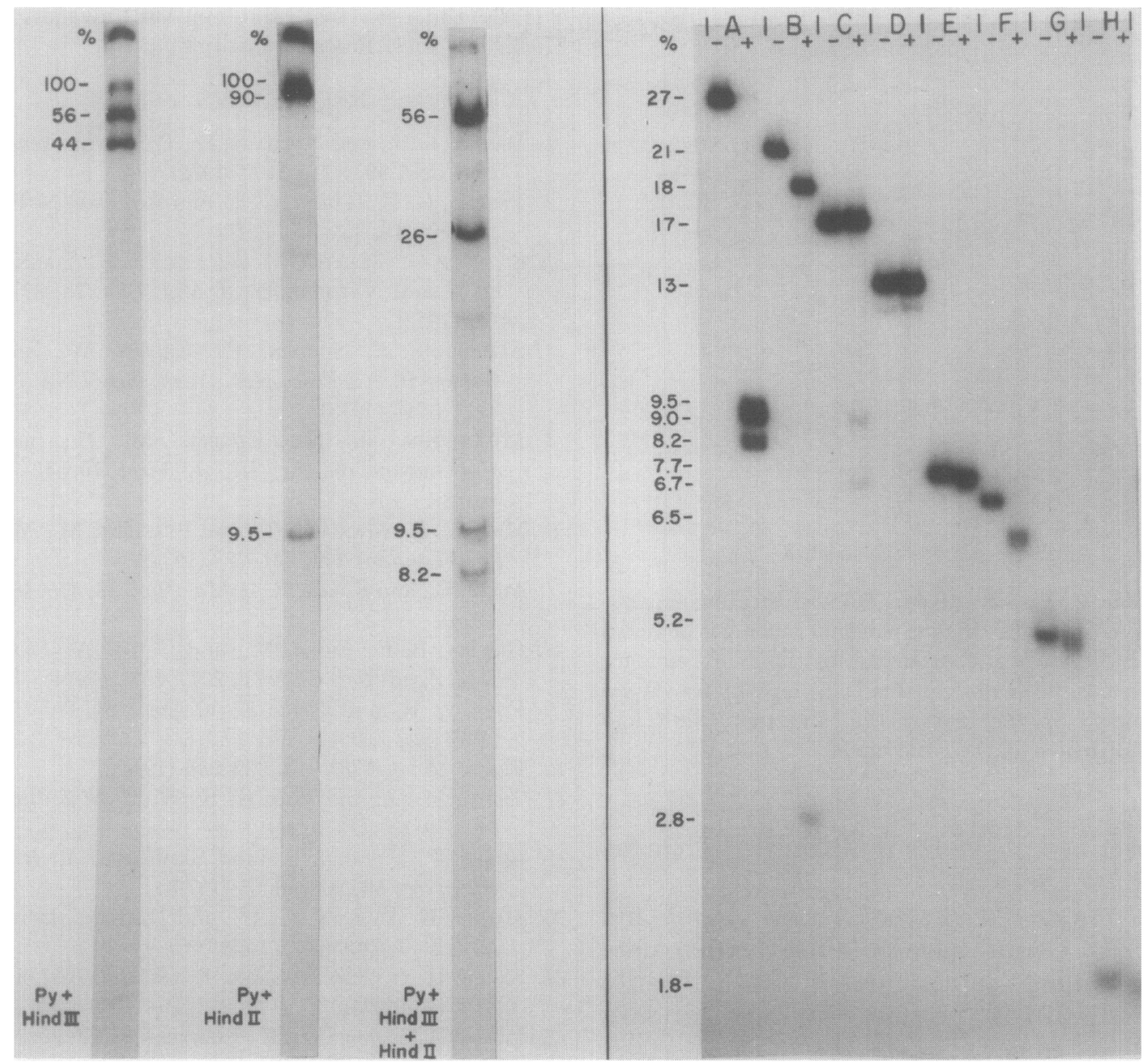

Fir. 1. Autoradingraph of polyoma DNA fragments separated by acrylamide slab gel electrophoresis. ${ }^{32} \mathbf{P}$ labeled DNA's were digested with $H$. influenzae endonucleases and the products were separated by electrophoresis on $30-\mathrm{cm}$ slab gels with a current of $40 \mathrm{~mA}$ at $15-20^{\circ}$ for $12-18 \mathrm{hr}$. All gels were run with one slot containing molecular weight standards as references. Origins are at the top of the figure. Left: 1 , Polyoma digested with HindIII; the material at $100 \%$ is linear DNA produced by a single cut. 2, Polyoma digested with HindII; the band at $90 \%$ runs slightly faster than the minor band of linear (single cut) DNA at 100\%. 3, Polyoma digested with a mixture of HindII and HindIII. Minor hands barely visible in 1,2 and 3 are probably partial digestion products. Right: Fragments of polyoma DNA generated by digestion with HpaII with and without subsequent digestion by HindII and HindIII. From left to right: slots containing fragments $\mathrm{A}-\mathrm{H}$ prior to and after digestion with HindII and HindIII. The double band at $9.0-9.5 \%$ generated by digestion of HpaII-A has twice the number of counts as the singlet band directly below it at $8 \%$ (as determined by liquid scintillation counting). The minor bands accompanying $\mathrm{HpaII}-\mathrm{C}$ and $-\mathrm{D}$ may be contaminating fragments or alternatively may reflect endonuclease sites present in viral genomes which have undergone DNA sequence reassortment (9; Folk and Fishel, unpublished results).

(5) ${ }_{\text {CAG } T \text { TCTG' }}^{\text {GAC }}$ 'The HindIII sites in HpaII-

$A$ and HpaII-B have the sequence (5) $\underset{\mathrm{T}}{\mathrm{A} \backslash \mathrm{AGCT} T \mathrm{~T}} \mathrm{~T}(14)$.

The sites recognized by the HindII en- zyme are identical to those cleaved by the restriction endonuclease HincIII from $\mathrm{He}$ mophilus influenzae $R c$ (15). We have purified the HincII enzyme and with it have obtained cleavage patterns of polyoma DNA and HpaII fragments identical to those 


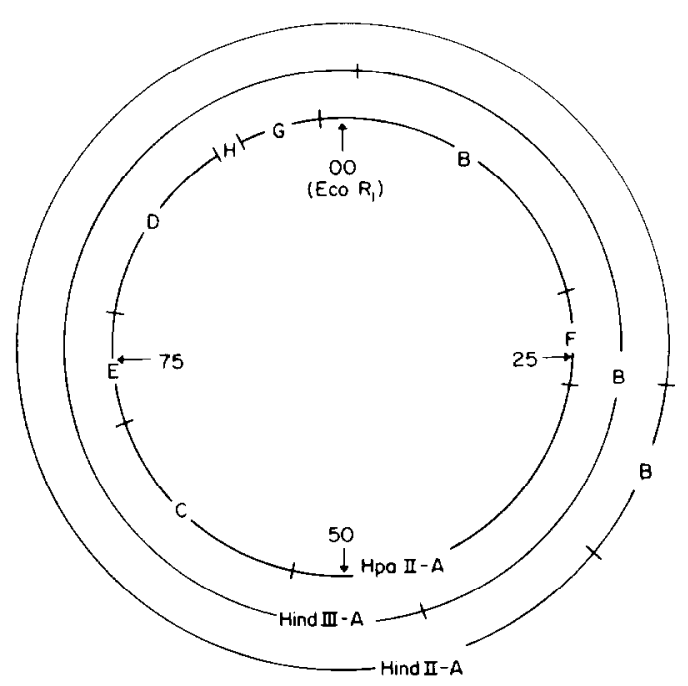

Fig. 2. Map of polyoma DNA illustrating endonuclease sites. The circular polyoma genome is depicted with the single site recognized by the EcoRI endonuclease $(8,9)$ at the top; the eight HpalI sites $(8)$ are depicted on the inner circle, and the HindII and HindIII sites on the outer circles.

described above for the HindII endonuclease (not shown).

Note added in proof. Dr. M. Yaniv and Dr. B. Griffin have obtained similar data confirming the assignment of HindII sites to HindIII-B (personal communications).

\section{ACKNOWLEDGMENTS}

We thank Dan Nathans for communicating unpublished results, and $\mathrm{H}$. O. Smith and A. Landy for bacterial strains. This work was supported in part by Grant No. CA-13978-02 from the National Institutes of Health and in part by a grant from The University of Michigan Cancer Research Institute.

\section{REFERENCES}

1. Danna, K. J., and Nathans, D., Proc. Nat. Acad. Sci. USA 69, 3097-3100 (1972).

2. Fareed, G. C., Garon, C. F., and Salzman, N. P., J. Virol. 10, 484-491 (1972).

3. Khoury, G., Martin, M. A., Lee, T. N., Danna, K. J., and Nathans, D., J. Mol. Biol. 78, 377389 (1973).

4. Sambrook, J., Sugden, B., Keller, W., and Sharp, P. A., Proc. Nat. Acad. Sci. USA 70, 3711-3715 (1973).

5. Middleton, J. H., Edgell, M. H., and Hutchinson, C. A., III, J. Virol 10, 42-50 (1972).

6. Maurer, R., Maniatis, T., and Ptashine, M., Nature (London) 249, 221-223 (1974).

7. Allet, B., and Solem, R., J. Mol. Biol. 85, 475-484 (1974).

8. Griffin, B. E., Fried, M., and Cowie, A., Proc. Nat. Acad. Sci. USA 71, 2077-2081 (1974).

9. FolK, W. R., and WANG, E., Virology, 61, 140-155 (1974).

10. Fried, M., J. Virol. 13, 939-946 (1974).

11. Smith, H. O., and Wilcox, K. W., J. Mol. Biol. 51, 379-391 (1970).

12. Sharp, P., Sugden, B., and Sambrook, J., Biochemistry 12, 3055-3063 (1973).

13. Danna, K. I., Sack, G. H., and Nathans, D., $d$. Mol. Biol. 78, 363-377 (1973).

14. Smith, H. O., and Nathans, D., J. Mol. Biol. 81, 419-423 (1973).

15. Landy, A., Ruedisveli, E., Robinson, L., Foeller, C., and Ross, W., Biochemistry 13, 2134-2142 (1974).

16. Garfin, D. E., and Goodman, H. M., Biochem. Biophys. Res. Commun. 59, 108-116 (1974).

17. Kelly, T. J., and SMith, H. O., J. Mol. Biol. 51, 393-409 (1970). 